\title{
THE VIRGILIAN CENTO PROGNE ET PHILOMELA (ANTH. LAT. 13 R): TOWARDS A SOLUTION FOR A MYTHOLOGICAL RIDDLE
}

\begin{abstract}
This paper deals with the 24-line mythological epyllion Progne et Philomela (Anth. Lat. 13 R), an anonymous Virgilian cento of presumed North African origin, which is usually dated to the fourth or fifth century and is marked by considerable obscurity. The aim is to shed some light on the most intriguing parts of this elliptical retelling of the given myth, in particular the puzzling network of family relationships and the extended talking-blood metaphor. Offering a new perspective on the text, the author claims that its general ambiguity is, to some extent, a purposefully adopted authorial strategy rather than a by-product of the cento technique. For this reason, it is proposed that the poem might have been written as a sort of mythological riddle to be solved by its readers.
\end{abstract}

Keywords: cento; Procne; Philomela; Virgil; mythology; riddle

Unlike other writers, authors of centos work within a limited corpus of pre-existing poetic expressions. The aesthetic value of any patchwork poem is thus inevitably a combined result of the author's skill and the expressive possibilities of the source text. It comes as no surprise, then, that a degree of obscurity has been identified (and criticized) in many of the centos that survive from Late Antiquity. This is also the case with the 24-line cento Progne et Philomela, ${ }^{1}$ one of the seven mythological epyllia-fashioned out of Virgil-that are contained in the Codex Salmasianus of the Latin Anthology (Anth. Lat. 9-15 R). This text of unknown authorship and presumed North African provenance is usually dated (together with other anonymous centos from Virgil) to the fourth or fifth century. ${ }^{2}$ Despite its conciseness, the cento's retelling of the story of King Pandion's daughters offers a rather rich reading. The text employs

\footnotetext{
${ }^{1}$ See especially K. Schenkl (ed.), 'Probae cento. Accedunt tres centones a poetis Christianis compositi', in Poetae Christiani minores I. CSEL 16 (Vienna, 1888), 511-639, at 539: 'Pessime conflatum est hoc carmen versibus ineptissime effictis, ita ut quid indicare voluerit scriptor plerumque difficile sit intellectu.' Cf. F. Ermini, Il centone di Proba e la poesia centonaria latina (Rome, 1909), 45; G. Salanitro, 'Osidio Geta e la poesia centonaria', $A N R W 2.34 .3$ (Berlin and New York, 1997), 2314-60, at 2342-3; S. McGill, Virgil Recomposed: The Mythological and Secular Centos in Antiquity (Oxford and New York, 2005), 82; M.T. Galli (ed. and transl.), I Vergiliocentones minores del codice Salmasiano (Florence, 2014), 20; and M. Bažil, 'Epic forms and structures in late antique Vergilian centos', in C. Reitz and S. Finkmann (edd.), Structures of Epic Poetry. Vol. III: Continuity (Berlin and Boston, 2019), 135-73, at 156.

${ }^{2}$ Cf. e.g. recently W. Fels (transl.), Anthologia Latina mit den Vergil-Centonen (Stuttgart, 2014), 8-9. Galli (n. 1), 4-5 proposes a slightly later dating (from the end of the fifth to the beginning of the sixth century) and McGill (n. 1), 72 emphasizes that the anonymous mythological centos from Virgil may have been written any time between c.A.D. 200, when the cento tragedy Medea, probably the oldest of the surviving late antique patchwork poems, was very likely composed, and c.A.D. 534, when the texts preserved in the Codex Salmasianus were gathered by an unknown compiler in Vandal Africa (i.e. shortly before the fall of the Vandal Kingdom).

(C) The Author(s), 2021. Published by Cambridge University Press on behalf of The Classical Association. This is an Open Access article, distributed under the terms of the Creative Commons Attribution-NonCommercial-

NoDerivatives licence (http://creativecommons.org/licenses/by-nc-nd/4.0/), which permits non-commercial re-use, distribution, and reproduction in any medium, provided the original work is unaltered and is properly cited. The written permission of Cambridge University Press must be obtained for commercial re-use or in order to create a derivative work.
} 
ingenious allusive strategies, and, as will be argued below, it turns out to be purposefully ambiguous rather than obscure, resembling a mythological riddle to be solved by its readers. ${ }^{3}$

\section{THE PUZZLE OF FAMILY RELATIONSHIPS}

What leads me to believe that the cento might have been written as a sort of mythological puzzle is the existence of several versions of the myth and a lack of explicit affiliation to any of them within the text. Of particular significance is that the author of the Progne et Philomela, as noted by Raffaele Perrelli, does not intentionally designate any of the protagonists by their proper names even though these were readily available in Virgil, ${ }^{4}$ who elliptically told the same story in the sixth book of his Eclogues (6.78-81). ${ }^{5}$ The word philomela in line 3 of the cento's four-line aetiological prologue (see below) seems to correlate with the term hirundo in line 1 and should therefore be taken (in line with its original context in $G$. 4.511) as a common rather than proper noun. ${ }^{6}$ In the rest of the poem, individual characters are referred to predominantly by words expressing their family relationships. While it is obvious that nouns such as tyrannus (lines 8, 16), (Threicius) rex (line 10), amans (line 14) and genitor (lines 21, 23) are all meant to characterize Tereus and that puer (lines 8, 20), progenies (line 9) and natus (line 23) denote his son Itys, it is much more difficult to say which of the two sisters is to be understood as the coniunx (lines 11, 24) / mater (line 7) and which as the uirgo (line 6) / soror (lines 16, 24).

In ancient literary traditions we come across three different versions of the myth. According to the Greek (Sophoclean) version, Procne is the wife of Tereus and the mother of Itys and becomes a nightingale, while Philomela plays the role of the raped sister, who is transformed into a swallow. In Latin renderings, in contrast, Procne turns into a swallow and Philomela into a nightingale, while their roles as the wife/mother and the sister are interchangeable. ${ }^{7}$ To make subsequent references to these variants easier, the following schematic overview of the evolution of the myth may be of use.

${ }^{3}$ Cf. P. Paolucci, 'La voce del sangue. Emendamento al centone virgiliano Progne et Philomela (AL 13, 18-19 R. ${ }^{2}$ '), GIF 55 (2003), 265-71, at 271; and McGill (n. 1), 82-3.

${ }^{4}$ R. Perrelli, 'Il centone virgiliano Progne et Philomela', in C. Moreschini (ed.), Esegesi, parafrasi e compilazione in età tardoantica. Atti del Terzo Convegno dell'Associazione di Studi Tardoantichi (Naples, 1995), 323-9, at 323-4, who observes that the cento is marked by 'una evidenza, in un certo senso, enigmistica'.

${ }^{5}$ Contrariwise, some other centonists had to be highly inventive in finding ways to identify the protagonists of their stories by means of Virgil. For example, the author of the Hercules et Antaeus (Anth. Lat. $12 \mathrm{R}$ ) made use of the name of a Rutulian fighter to denote Hercules' adversary (line 4: Aen. 10.561), and the author of the Medea (Anth. Lat. 17 R) identified the princess of Colchis using the phonetically similar geographical name Media (line 191: G. 2.126).

6 The centonist could not use the term luscinia, because it does not occur anywhere in Virgil.

${ }^{7}$ For a comprehensive overview of Latin treatments of the myth, see e.g. A. Casanova, 'Filomela da rondine a usignolo', in C. Santini, L. Zurli and L. Cardinali (edd.), Concentus ex dissonis. Scritti in onore di Aldo Setaioli. Vol. I (Naples, 2006), 165-78. Cf. B. Gibson (ed. and transl.), Statius, Silvae 5 (Oxford, 2006), 297-8, who argues that at Silv. 5.3.83-4 Philomela is to be identified as a swallow rather than as a nightingale, taking murmure trunco in line 83 as a reference to the specific sound of the bird and as a memento of Tereus' violent excision of Philomela's tongue. 


\begin{tabular}{|l|l|l|l|}
\hline \multirow{2}{*}{$\begin{array}{c}\text { Version 1 } \\
\text { (Soph. Ter.) }\end{array}$} & Procne & wife/mother & nightingale \\
\cline { 2 - 4 } & Philomela & sister & swallow \\
\hline $\begin{array}{c}\text { Version 2 } \\
\text { (Verg. Ecl. 6.78-81) }\end{array}$ & Philomela & wife/mother & nightingale \\
\cline { 2 - 4 } & Procne & sister & swallow \\
\hline $\begin{array}{c}\text { Version 3 } \\
\text { (Ov. Met. 6.412-674) }\end{array}$ & Procne & wife/mother & swallow \\
\cline { 2 - 4 } & Philomela & sister & nightingale \\
\hline
\end{tabular}

The answer to the question of which version of the story is actually followed in the cento is, in my view, implied in its prologue (lines 1-4):

aspice ut insignis (Aen. 6.855) uacua atria lustrat (Aen. 2.528) hirundo! (Aen. 12.474)

uere nouo ( $G$. 1.43) maestis late loca questibus implet; $(G .4 .515)$

uictum infelicem (Aen. 3.649) maerens Philomela sub umbra (G. 4.511)

adsiduo resonat cantu (Aen. 7.12) miserabile carmen. $(G .4 .514)^{8}$

This passage is most probably to be read as a prefiguration of the metamorphosis of both sisters, one into a swallow (line 1) and the other into a nightingale, noted for its sorrowful song (lines 2-4). ${ }^{9}$ This interpretation makes the punctuation adopted in the overwhelming majority of editions somewhat misleading and the capitalization of the generic noun philomela unfounded. ${ }^{10}$ In fact, the proem seems to correspond with the cento's final line, which describes the transformation of both women (line 24): et soror et coniunx petierunt aethera pinnis. ${ }^{11} \mathrm{We}$ can therefore reasonably suppose that the swallow (hirundo) first mentioned in the prologue foreshadows the fate of Philomela's sister Procne (soror), while the nightingale (philomela) anticipates the metamorphosis of Tereus' wife Philomela (coniunx). ${ }^{12}$ In short, it appears that the centonist drew inspiration from his primary source - that is, from Virgil (Ecl. 6.78-81) and adopted the second version of the myth. ${ }^{13}$

This hypothesis is further confirmed by several allusions to Virgil's handling of the story in the Eclogues to be found in the concluding part of the cento (lines 22-4):

polluit ore dapes, (Aen. 3.234) quidquid solamen humandi est. (Aen. 10.493)

dum genitor nati (Aen. 10.800) morsu depascitur artus (Aen. 2.215)

et soror et coniunx (Aen. 1.47) petierunt aethera pinnis. (Aen. 11.272) $)^{14}$

\footnotetext{
${ }^{8}$ Unless specified otherwise, the cento is quoted according to the most recent edition by Galli (n. 1).

${ }^{9}$ For other possible, but less likely, readings of the passage, see M. Okáčová, Centones Vergiliani. Klasická poezie 'pod kaleidoskopem' (Prague, 2016), 139-40.

${ }^{10}$ For a more detailed discussion of the matter, see Okáčová (n. 9), 140 n. 504.

${ }^{11}$ Cf. Galli (n. 1), 21, who speaks about the 'Ringkomposition' of the cento.

12 This conclusion is supported also by the original context of the quotations from Georgics Book 4 (a comparison of Orpheus lamenting the loss of Eurydice to the nightingale mourning her lost brood) in lines 2-4 of the cento; see M. Okáčová, 'Mythological epyllia written in the form of Virgilian centos: a model case of intertextuality', GLB 15 (2010), 139-54, at 150 n. 37; and ead. (n. 9), 137.

13 The same opinion is held by Paolucci (n. 3), 271 n. 21; McGill (n. 1), 81; and Galli (n. 1), 20 and 155-6. In contrast, Perrelli (n. 4), 324 supposes that the cento employs the third version of the myth, and Salanitro (n. 1), 2342 seems to believe that the poem can be understood on the basis of the Sophoclean version.

${ }_{14}$ Quoted according to Galli (n. 1) with a small change in the punctuation in line 22 (cf. n. 31 below).
} 
This passage clearly echoes $E c l$. $6.78-81$ :

aut ut mutatos Terei narrauerit artus, quas illi Philomela dapes, quae dona pararit, quo cursu deserta petiuerit, et quibus alte infelix sua tecta super uolitauerit alis?

The imitation of Virgil by means of his own lines is achieved through purely lexical means - the words artus and dapes, forms of the verb petere (petierunt/petiuerit) and the ablative plurals pinnis and alis, both of them placed in final positions in verse. ${ }^{15}$

\section{(INTENTIONAL) AMBIGUITY}

From the above, it becomes clear that the cento challenges the readers' knowledge of the myth and plays with their expectations. Such an effect is certainly produced by the use of the gender-neutral noun coniunx in the charge of guilt in lines 5-6 (causa mali tanti coniunx, thalamique cruenti | uirginis os; notumque furens quid femina possit). While elsewhere in the poem (lines 11 and 24) the word obviously refers to Tereus' wife, in this case both the husband (Tereus) and his wife (Philomela) come into play as possible referents. ${ }^{16}$ Both of them are, after all, guilty of a crime against morality-Tereus raped his sister-in-law and Philomela killed her own child. Without necessarily having to decide who the major villain is, readers are confronted with a teasing ambiguity, which makes them think about the story in terms of crime and revenge.

Another moment in the cento invested with ambiguous meaning, this time with an added touch of irony, may be found in lines 9-10: progeniem paruam curaeque iraeque coquebant | Threicio regi, ... As observed by Scott McGill, this image works both literally and figuratively. ${ }^{17}$ On a literal level, it foreshadows the fate of Itys who is to be cooked and served as a meal to Tereus; metaphorically, it may refer to the passions (namely distress and seething anger) boiling in the heart of Philomela and ultimately leading to an act of violence against her own child. The latter, less obvious meaning of the verb coquere is actually in line with its original context in Aen. 7.345, which describes the emotional turmoil of Queen Amata standing on the threshold of madness.

\section{TALKING-BLOOD IMAGERY}

Perhaps the most challenging part of the entire cento, at least for modern scholarship, is the blood imagery in lines 15-20:

pectore in aduerso (Aen. 9.347) saeui monumenta doloris (Aen. 12.945)

fertque refertque soror, (Aen. 4.438) crimenque, (Aen. 12.600) facta tyranni (Aen. $8.483)$

sanguis ait solide. (Aen. 2.639) postquam data copia fandi (Aen. 1.520/11.248)

uulnera siccabat (Aen. 10.834) circum praecordia, sanguis (G. 2.484)

accepit uocem (Aen. 12.64) et saeuo sic pectore fatur: (Aen. 12.888)

'heu, miserande puer, (Aen. 6.882) nunc te fata impia tangunt!' (Aen. 4.596)

15 See also Okáčová (n. 12), 150-1; and ead. (n. 9), 147-8.

${ }^{16}$ For arguments in favour of the latter alternative, see Okáčová (n. 9), 136 n. 489.

17 McGill (n. 1), 82-3; for critical comments on McGill's interpretation, see Okáčová (n. 9), 142-3. 
The recurring motif of blood can be interpreted as a symbol of (disrupted) family relationships, another of the cento's leitmotifs. ${ }^{18}$ When the image of blood appears for the first time (lines 5-6 causa mali tanti coniunx, thalamique cruenti | uirginis $o s ; . .$.$) , it is to be taken literally as tangible evidence of the violence committed against$ the virgin Procne- that is, of her rape by Tereus. The talking-blood imagery employed later in the poem (lines 15-20) has a clearly metaphorical (and presumably aetiological) significance, referring both backward to the crime committed by Tereus and forward to the killing of Itys.

Having previously assigned the roles of wife/mother and sister to Philomela and Procne respectively, we can proceed to examining the question of whose blood is actually talking in the cento, which entails addressing some textual-critical problems. In the first part of the metaphor (lines 15-17), it is clearly the blood of the raped and mutilated sister (Procne) that serves (in place of her severed tongue) as the medium of communication, specifically as the means of crime revelation. The cento shares this motif with two other anonymous poems on the myth preserved in the Codex Salmasianus of the Latin Anthology, ${ }^{19}$ differing in this respect from the classical version, according to which the raped woman wove the story of her suffering into a garment and sent it to her sister. The talking-blood motif probably derives from a detail given in Ovid, where Philomela weaves her story with purple on a white background (Met. 6.577 purpureasque notas filis intexuit albis), ${ }^{20}$ and it might have become a sort of topos in late antique, presumably African, renderings of the myth. ${ }^{21}$

The question is how to interpret the second part of the extended blood metaphor (lines 17-20), where blood pronounces a verdict on Itys. Having no parallel in other treatments of the myth, this particular image is probably the author's innovative elaboration of the role of blood in the story. Rather than belonging to the speechless Procne, whose blood has already borne witness to Tereus' crime, this voice of blood seems to belong to the other sister, whose status as the wife of Tereus and mother of Itys makes the threatening exclamation in line 20 (heu, miserande puer, nunc te fata impia tangunt!) all the more pathetic. ${ }^{22}$

The belief that in the cento the blood of both sisters has something to say is also supported by the inverted repetition of two keywords in the passage under discussion: pectore and sanguis. Occurring in prominent positions in their respective hexameters, these words create a sort of chiastic parallelism, which may help us to understand the inner logic of the blood imagery. When they occur for the first time, both nouns are found at the beginnings of verses (pectore, 15; sanguis, 17), functioning as a semantic frame for the first part of the metaphor. The focus is clearly on past events, on Tereus' rape of Procne and his subsequent severing of her tongue, a memento of which is her bloodstained chest. The second occurrence of the same words, only in reverse order and in final (or nearly final) positions in verse (sanguis, 18; pectore, 19), then

${ }^{18}$ Cf. Perrelli (n. 4), 324.

19 Anth. Lat. 14.2-3 tristis post funera linguae | sanguis adest pingitque cruor tormenta pudoris; Anth. Lat. 51 sanguine muta probat facinus Philomela sorori| uimque uicem linguae sanguine muta probat (quoted and referenced according to D.R. Shackleton Bailey [ed.], Anthologia Latina I.1 [Stuttgart, 1982]).

${ }^{20}$ See Paolucci (n. 3), 265-6, who refers to Servius' commentary on Ecl. 6.78, according to which Philomela actually used her own blood: illa tamen rem in ueste suo cruore descriptam misit sorori: ...

${ }^{21}$ See McGill (n. 1), 82.

22 On sources of pathos in the cento, see Perrelli (n. 4), 324; McGill (n. 1), 82; and Okáčová (n. 9), 137 n. 490. 
foreshadows the crime that will be committed in revenge for Tereus' conduct by his wife Philomela (probably together with her sister Procne) - that is, the killing of Itys, whose blood will stain the breast of his murderer(s) as a memento of the crime.

This lexical parallelism thus strongly corresponds with and emphasizes the theme of crime and punishment in the cento. In addition, it seems to have an aetiological significance similar to that of the prologue. A competent reader may recognize the aforementioned keywords as lexical allusions to an aetiological portrayal of Procne-swallow, as found in Ovid (Ars am. 2.383-4 altera dira parens haec est, quam cernis hirundo: | adspice, signatum sanguine pectus habet!), whose description is clearly inspired by Virgil (G. 4.15 et manibus Procne pectus signata cruentis); cf. aspice in the cento's opening line and pectore together with sanguis in the blood metaphor in lines 15-19. Both Ovid and Virgil mention the bloodstained chest as a distinguishing feature of the swallow. Whereas Virgil's reference to the story of Procne is open to interpretation, ${ }^{23}$ in Ovid, who clearly follows the third version of the myth with Procne-swallow playing the role of mother and wife, the stain of blood is obviously a memento of the killing of her own offspring.

The echo of Ovid's Ars amatoria in the cento, identified by Raffaele Perrelli, ${ }^{24}$ strengthens the aetiological interpretation of lines 18-19 proposed by Paola Paolucci. ${ }^{25}$ According to Paolucci, these lines foreshadow the metamorphosis of the mother of Itys, implied also by the transition from the perfect form accepit to the present fatur. In line 17, Paolucci reads solidae, assuming that this adjective characterizes the severed tongue as a mutilated organ covered with coagulated blood; ${ }^{26}$ in line 19 , she proposes to read Virgil's original accepit uocem (Aen. 12.64) instead of the somewhat troublesome emendation accipe <ait> uocem, proposed by Pieter Burman (1759) and adopted in the absolute majority of subsequent editions despite the fact that such an expression does not occur in Virgil. ${ }^{27}$ Thus, her reading of the blood metaphor (lines 17-20) is the following: after the mute tongue had been given an opportunity to speak, blood (that of the second sister) took the floor and from a sorrowful heart pronounced a verdict on the pitiable boy. ${ }^{28}$ However plausible this interpretation is, it involves a potential contradiction in the aetiological moment; Philomela, who is most likely identified as the mother of Itys in the cento, is changed into a nightingale, which certainly has no bloodstain on its chest. ${ }^{29}$

${ }^{23}$ See the exhaustive account provided by Casanova (n. 7), 167-70.

${ }^{24}$ Perrelli (n. 4), 327.

${ }^{25}$ Paolucci (n. 3), 268-71.

${ }^{26}$ solidae: A. Riese (ed.), Anthologia Latina I.1 (Leipzig, 1869, 1894²), no. 13; E. Baehrens (ed.), Poetae Latini minores IV (Leipzig, 1882), no. 203; G. Salanitro (ed. and transl.), Silloge dei Vergiliocentones minori (Acireale and Rome, 2009), 48. solitae: P. Burman (ed.), Anthologia veterum Latinorum epigrammatum et poematum sive catalecta poetarum Latinorum in VI. libros digesta. Vol. I (Amsterdam, 1759), no. I 168; H. Meyer (ed.), Anthologia veterum Latinorum epigrammatum et poematum. Vol. I (Leipzig, 1835), no. 689. solide: Galli (n. 1), 150.

${ }_{27}$ Burman (n. 26), no. I 168; Meyer (n. 26), no. 689; Riese (n. 26), no. 13; Baehrens (n. 26), no. 203 (accipe uocem <ait); Salanitro (n. 26), 48; accepit uocem: Galli (n. 1), 150.

${ }^{28} \mathrm{Cf}$. the translation of the same passage (lines 15-19 according to Riese [n. 26]) offered by McGill (n. 1), 81, who also seems to suppose that the blood of each sister plays a role in this rendering of the myth: 'Procne's blood tells of the crime and deeds of the king. After Philomela had recovered her wits enough to speak, she was staunching the wounds around her heart, and she said, "Blood, receive a voice" [i.e., I give you a voice, because I have understood what you mean to communicate].'

${ }^{29}$ On this incongruity in her reading, see Paolucci (n. 3), 271 n. 21. 
A different line of interpretation is taken by the cento's most recent editor Maria Teresa Galli. ${ }^{30}$ While she adopts the emendation accepit uocem in line 19 proposed by Paolucci, she is the first to correct the preserved solite in line 17 to solide, translating it as 'completamente'. ${ }^{31}$ Galli argues that this adverb refers back to the revelation of Tereus' crime brought about by the blood of Procne and should therefore be shifted to the end of the first colon stretching across lines 15-17. Unlike Paolucci, she assumes that the blood metaphor concerns in its entirety only the violated sister-that is, Procne, whose change into a swallow with a red sign on its breast is thus prefigured. ${ }^{32}$ In her aetiological reading, Galli repeatedly refers to the above-quoted description of Procne-swallow in Ovid's Ars amatoria (2.383-4) and Virgil's Georgics (4.15) as well as to a passage in Ovid's Metamorphoses (6.667-70) where the story of Pandion's sisters reaches its climax through their transformation: ${ }^{33}$ corpora Cecropidum pennis pendere putares: | pendebant pennis. quarum petit altera siluas, | altera tecta subit; neque adhuc de pectore caedis | excessere notae, signataque sanguine pluma est. On the basis of these literary sources, Galli comes to the conclusion that the stain of blood on the swallow's chest should be taken as a token of Procne's glossotomy rather than as a memento of the killing of Itys. ${ }^{34}$ However, the latter is without a doubt the intended significance in Ovid's Ars amatoria, where it is clearly stated that Procne-swallow plays the role of mother (parens, 2.383), which adds an exemplary quality to her impious deed. Both Ovid in the Metamorphoses and Virgil in the Georgics seem to follow one and the same tradition regarding the myth. ${ }^{35}$ This makes the interpretation put forward by Galli somewhat less convincing. In addition, it is difficult to see a reason why Procne's blood should pronounce a death sentence on Itys when Philomela is able to speak and her reaction to her sister's violation would be only a logical outcome to the revelation scene.

For the reasons provided above, we may need to look for yet another reading of the blood imagery, which involves choosing among some textual options. Even though the ingenious emendation to solide proposed by Galli in line 17 is palaeographically reasonable, the same is true of Virgil's original solidae (Aen. 2.639), which, in my view, makes better sense in the context, providing an anaphoric reference to the unusual means of crime revelation in the first colon and a subject for the verb siccabat in the second. ${ }^{36}$ Moreover, the idea of a severed tongue preserving its original function, as

${ }^{30}$ Galli (n. 1), 164-73.

${ }^{31}$ Galli (n. 1), 150-1; cf. nn. 26-7 above. In addition, Galli (n. 1), 150 has, in my view, unnecessarily extended the direct speech of the blood to lines 21 and 22 of the cento: 'heu, miserande puer, nunc te fata impia tangunt | regalis inter mensas genitoris et ora! | polluit ore dapes, quidquid solamen humandi est' (lines 20-2; cf. her translation of these lines in n. 32).

32 See Galli's ([n. 1], 151) translation of lines 15-22 of the cento: 'In pieno petto la sorella porta e riporta la testimonianza dell'atroce dolore, e il sangue rivela completamente la colpa, i misfatti del tiranno. Dopo che la possibilità data di esprimersi asciugava le ferite intorno al cuore, il sangue prese voce e con cuore crudele disse così: "ahimè, fanciullo degno di compassione, ecco che ora durante il pasto e sotto gli occhi del sovrano tuo padre, ti raggiunge il tuo funesto destino! Egli profana con la sua bocca il cibo, (ovvero) tutto ciò cui sarebbe un conforto dare sepoltura".'

${ }^{33}$ Ovid, similarly to the centonist (line 24 et soror et coniunx petierunt aethera pinnis), does not explicitly state which of the sisters becomes a nightingale and which a swallow.

${ }^{34}$ Cf. Serv. Ecl. 6.74 modo ergo Vergilius aut poetarum more miscuit fabulas et nomen posuit pro nomine, ut diceret ...; item et manibus Procne pectus signata cruentis, cum Philomelae, non Procnes, abscisa sit lingua ...

${ }^{35}$ See e.g. Casanova (n. 7), 167-72. Cf. n. 7 above.

36 Paolucci (n. 3), 270 n. 18 plausibly suggests that the predicate siccabat in line 18 is probably used intransitively, with uulnera assuming the function of an accusative of respect. 
implied in line 17 (solidae postquam data copia fandi), ${ }^{37}$ resonates with the image of Orpheus' head floating down the river and constantly calling out for Eurydice, evoked in line 13 of the cento (uox ipsa <et frigida lingua, G. 4.525). ${ }^{38}$ In line 19, Paolucci's emendation to accepit uocem seems to be a much more sensible choice than the direct speech accipe <ait uocem addressed to blood, which does not make much sense, whether delivered by the speechless Procne or by Philomela.

Having resolved these textual-critical questions, we can once again try to explain the significance of the talking-blood metaphor, which, in my view, relates to both sisters. In addition to its aetiological implications, the blood imagery perfectly emphasizes, as mentioned earlier, the leitmotif of (disrupted) family relationships in the cento. The passage under discussion thus adds resonance to the blood relationship between Procne and Philomela, two sisters whose fates are closely intertwined by Tereus' violent crime and by their bloody revenge for it. This family reciprocity is clearly accentuated by the repetition of the keywords pectore and sanguis, which specify the location of the bloodstains revealing Tereus' crime and thus prefigure the bloody response of Philomela, uttered with a merciless heart (line 19 saeuo sic pectore fatur). ${ }^{39}$ In terms of aetiology, these keywords foreshadow Procne's transformation into a swallow with a bloodstained chest (perhaps as a memento of the killing of Itys), possibly together with Philomela's metamorphosis into a nightingale. ${ }^{40}$ Lines $15-20$ of the cento can accordingly be translated as follows: 'Procne's chest, full of animosity, constantly bears a reminder of a terrible pain, and her blood tells of the tyrant's horrible crime. After the congealed blood had had the opportunity to speak, while (Procne's) wounds around her heart were healing, (Philomela's) blood took the floor and with unrelenting heart said: "Oh poor boy, impious fate will now afflict you!"”

The puzzling image of blood that suddenly begins to speak can be thought of as a play on the polysemy of the word sanguis, which means 'blood' as well as 'bloodshed' and 'consanguinity'. ${ }^{41}$ In the context of the story, all of these meanings are obviously relevant, emphasizing the blood relationships between Procne and Philomela, on the one hand, and between mother (Philomela) and son (Itys), on the other. While it is most probably Philomela's blood that is actually threatening Itys, her reaction has been provoked by the bloodstains visible on Procne's chest. This makes blood, a body fluid considered to respond to one's emotions, not only a symbol of a close relationship between the two sisters but also a powerful medium of their communication.

\section{CONCLUSION}

As we have seen, the cento Progne et Philomela is far from crystal clear. The number of existing versions of the myth, together with the way in which the poem is written, makes

${ }^{37}$ Quoted according to Salanitro (n. 26).

38 See Paolucci (n. 3), 270 n. 18; on the role of the Orpheus myth in the cento, see Okáčová (n. 12), 149-50; and ead. (n. 9), especially 141.

39 Cf. Galli (n. 1), 164-5.

${ }^{40}$ Cf. Okáčová (n. 9), 151-4.

41 A similar idea might have inspired Salanitro's ([n. 26], 49) translation of the passage (lines 15-20); see especially his apostrophe of blood: 'Nel cuore ostile la sorella porta e riporta il ricordo del crudele dolore, e il sangue svela la colpa e le malefatte del tiranno. Dopo che a lei irremovibile è data la possibilità di parlare (asciugava le ferite intorno al cuore) "Sangue mio" - dice - "ascolta la mia voce", e così parla con cuore spietato: "Ahimé, fanciullo degno di pianto, ora ti tocca un crudele destino".' 
it resemble a compelling mythological puzzle. Indeed, the cento openly plays with the readers' knowledge of the myth variants, forcing them to reconstruct the complex network of family relationships together with the storyline itself. For this reason, we can plausibly assume that the general ambiguity of the poem is, at least to some extent, a purposefully adopted authorial strategy rather than a side-effect of the method of composition.

Of course, the proposed reading remains a pure conjecture, especially as no other (mythological or other) Virgilian cento from Late Antiquity invites being read in a similar fashion-that is, as an ambiguous riddle rather than as a patchwork text with a more-or-less obscured meaning. Nevertheless, the line of interpretation adopted for the Progne et Philomela may acquire further plausibility if we consider the largest extant collection of ancient Greek riddles in Book 14 of the Palatine Anthology, which contains (apart from arithmetical problems and oracles) more than fifty riddles in the traditional sense (almost all of them of uncertain date and authorship) ${ }^{42}$ concerning everyday objects and mythological figures. ${ }^{43}$ Among the mythological ones, there are two texts with the riddling principle based exclusively on family relationships and the underlying motif of crime and punishment, namely the two-line riddle about

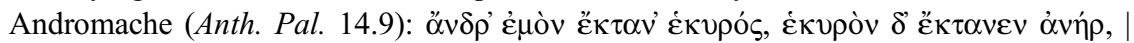

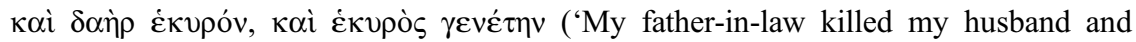
my husband killed my father-in-law; my brother-in-law killed my father-in-law, and my father-in-law my father'); and the riddle concerning Eteocles and Polynices (Anth.

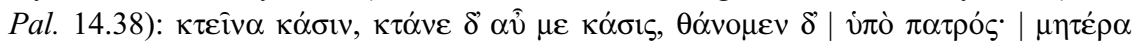

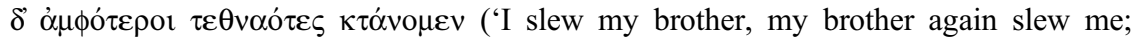
our death is caused by our father, and after our death we both kill our mother'). ${ }^{44}$ These two are really extreme examples; still, many of the other mythological (and other) riddles in the Palatine Anthology also include at least some hint at the parentage or other family ties of the figures concerned. ${ }^{45}$ Family relationships thus

42 The dating actually ranges from Archaic Greek to Byzantine times; see C. Luz, 'What has it got in its pocketses? Or, what makes a riddle a riddle?', in J. Kwapisz, D. Petrain and M. Szymański (edd.), The Muse at Play: Riddles and Wordplay in Greek and Latin Poetry (Berlin and Boston, 2013), 83-99, at 83 n. 1.

43 In Latin antiquity, riddles were not an unknown literary form either; unfortunately, only one complete collection survives, the famous Aenigmata Symphosii, composed probably in the late fourth or early fifth century and transmitted in the Codex Salmasianus of the Latin Anthology. This collection of 100 riddles in hexameters does not, however, include a significant number of mythological puzzles; the closest we get to mythology with Symphosius is riddles 31 (phoenix), 39 (centaurus) and 98 (Echo). Regarding Symphosius' identity, including his name and national origin (North African?), and the date of his collection, see e.g. T.J. Leary (ed.), Symphosius: The Aenigmata (London / New Delhi / New York / Sydney, 2014), 1-6. A taste of the variety of sources for ancient riddles is offered by S. Monda (ed.), Ainigma e griphos. Gli antichi e l'oscurità della parola (Pisa, 2012). Cf. further n. 45 below.

${ }^{44}$ Text and translation by W.R. Paton (ed. and transl.), The Greek Anthology. Vol. V (London and New York, 1918), 31.

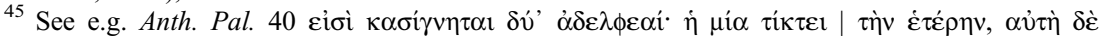

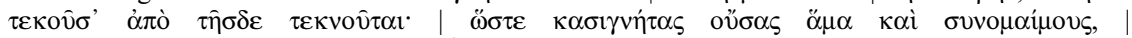
$\alpha$ v่ other, and herself having brought forth is born from the other, so that being sisters and of one blood they are actually sisters and mothers in common' [answer: day and night]); cf. Symph. Aenig. 37 (Mula): dissimilis matri, patri diuersa figura, | confusi generis, generi non apta propago, | ex aliis nascor nec quicquam nascitur ex me (quoted according to Leary [n. 43]). Regarding the significance of the genealogical motif in ancient riddles in general, see the late antique grammarians Diomedes (Gramm. Lat. 1.450.25 aenigma est per incredibilia confusa sententia, ut 'auia filiorum est 
seem to be a quite natural (and logical) means of teasing and taxing the readers' knowledge of particular mythological stories, in which genealogy very frequently plays a crucial role. ${ }^{46}$ And this is exactly what the author of the cento riddle seems to be doing-playing with readers and their expectations.

Masaryk University

MARIE OKÁČOVÁ marie.okacova@mail.muni.cz

quae mater mariti', cum Iocasta significetur) and Pompeius (Gramm. Lat. 5.311.5-12 aenigma est, quo ludunt etiam paruuli inter se, quando sibi proponunt quaestiunculas, quas nullus intellegit. dic mihi, quid est hoc, est quaedam filia matris et mater filia est filiae suae? hoc qui potest intellegere, mater me genuit, eadem mox gignitur ex me? aenigma est; hoc autem significat, aquam soluta glacie posse procreari, iterum ipsam aquam coactam glaciem posse facere. ergo et de aqua fit glacies, et de ipsa glacie fit aqua. aenigma est hoc), cited and referenced according to H. Keil (ed.), Grammatici Latini, 8 vols. (Leipzig, 1855-1880).

${ }^{46}$ On genealogy as an important ordering principle of ancient mythology, see e.g. I. Hahn, 'Vom Logos im Mythos. Mythenbildung, Mythendeutung und Mythenkritik in der griechischen Klassik', in E. Kluwe (ed.), Kultur und Fortschritt in der Blütezeit der griechischen Polis (Berlin, 1985), 129-57, at $136-9$. 